7. Введение в Angular [Електронний ресурс] - Режим доступу до ресурсу: https://metanit.com/web/angular2/1.1.php

8. Figure 1. Web-application development steps. [http://webworking.by/web-technology/infografika/infografika-natemu-etapy-sozdanie-sayta/]

9. Figure 2. MVC programming pattern [https://www.pinterest.com/pin/284289795201685213/]

\title{
МОДЕРНІЗАЦЯ СТРУКТУРИ СИСТЕМИ КЕРУВАННЯ ВИПАРНОЇ СТАНЦІЇ БУРЯКОЦУКРОВОГО ЗАВОДУ НА БАЗІ МІКРОПРОЦЕСОРНИХ ТЕХНІЧНИХ ЗАСОБІВ I ПРОГРАМ УКРАЇНСЬКОГО ВИРОБНИЦТВА
}

\author{
Скаковський Ю. М. ${ }^{1}$ Бабков А. В. ${ }^{2}$, Мандро О. Ю. ${ }^{3}$ \\ 1,2,3 Одеська національна академія харчових технологій, Одеса \\ ORCID: ${ }^{1} \underline{0000-0003-4888-4469} ;{ }^{2} \underline{0000-0002-9167-7804}$
}

Copyright (C) 2018 by author and the journal "Automation technologies and business - processes. This work is licensed under the Creative Commons Attribution International License (CC BY). http://creativecommons.org/licanses/by/4.0
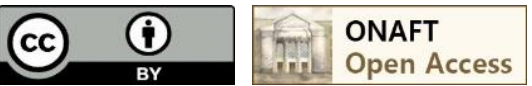

DOI: $10.15673 /$ atbp.v10i1.874

Анотація:Розглядаються технічні рішення з модернізації структури комплексу технічних засобів керуючої системи випарної станції иукрового заводу. Система керування побудована як автоматизоване робоче місие (АРМ) оператора на базі комп'ютера, мережі мікропроцесорних контролерів та регуляторів, датчиків та виконавчих механізмів. Мережа мікропроцесорних контролерів та регуляторів реалізована на базі перетворювача MODBUS RTU - USB типу БПI-452. АРМ включає також щит оператора для реалізаџї дистанційного режиму керування. Фронтальна сторона щита складається з двох панелей, де розташовані мікропрочесорні контролери та регулятори, а також прилади, щзо показують, та органи дистаниійного керування (задавачі). На внутрішніх панелях щзита розташована група мікропрочесорних регуляторів та приладів системи живлення. Система керування спроектована з використанням мікропрочесорних контролерів, приладів і програм Украӥнського виробництва, датчиків та виконавчих механізмів імпортного виробництва. Імітаційне моделювання проводилося на спеціалізованому стенді із застосуванням промислових контролерів і програм. Результати досліджень застосовані для модернізачії керуючої системи иукрового заводу.

Abstract:Technical solutions for modernization of technical facilities structure for control system of sugar plant evaporator station are considered. Control system is built as an automated workstation (AWS) of the operator based on the computer, microprocessor controllers and regulators network, sensors and actuators. The network of microprocessor controllers and regulators is launched on the basis of MODBUS RTU-USB converter BIP-452 type. Workstation also includes operator panel to implement remote control mode. Shield's front side consists of two panels within located microprocessor controllers and regulators and remote controls (reference-input element). Group of microprocessor regulators and power supply devices are located on the internal panels. The control system is designed using microprocessor controllers, devices and programs of Ukrainian production, sensors and actuators of imported production. Simulation modeling was conducted on specialized stand with the use of industrial controllers and programs. The results of research were used to modernize the control system of the sugar factory.

Ключові слова: Система автоматичного керування, автоматизоване робоче місце оператора, мікропроцесорний контролер, випарна станція, цукровий завод. 
Keywords: System of automatic control, workstation of operator, microprocessor-based comptroller, evaporated station, sugar-house.

Вступ. В Одеській національній академії харчових технологій у рамках госпдоговірної тематики виконуються роботи $з$ надання науково-технічної допомоги при модернізації систем автоматизації для підвищення ефективності їхнього функціонування на Красилівському бурякоцукровому заводі (Хмельницької області). Створена багаторівнева автоматизована система керування технологічними процесами (АСКТП) бурякоцукрового виробництва, що включає автоматизовані робочі місця (АРМ) операторів основних технологічних ділянок, АРМи диспетчера, головного технолога й директора на базі мікропроцесорних контролерів, комп'ютерів і локальної мережі на базі технології Ethernet [1]. У цей час виконані роботи з модернізації системи автоматизації випарної станції (ВС), що включає, так зване, «конденсатне господарство».

Основні технічні рішення. Модернізація системи автоматизації ВС виконувалась у відповдності до змін теплової схеми «конденсатного господарства», що передбачало заміну збірників конденсату та встановлення додаткових випарювачів конденсату для першого та другого корпусів ВС із метою підвищення ефективності використання вторинної пари та тепла конденсатів.

На рис. 1 наведена структура комплексу технічних засобів (КТЗ) АРМ оператора ВС до модернізації, що об'єднувала датчики, перетворювачі, виконавчі механізми, мікропроцесорний контролер (централізованого типу, виробництва фірми «Мікрол», м. Івано-Франківськ, Україна), персональний комп'ютер оператора iз SCADAсистемою «ІНДЕЛ» (розробка - фірми «Інфотехпром», м. Полтава, Україна) та щит оператора для реалізації функцій дистанційного контролю та керування. Система керування розроблялася за участю співробітників кафедри автоматизації виробничих процесів ОНАХТ у 2006 році.

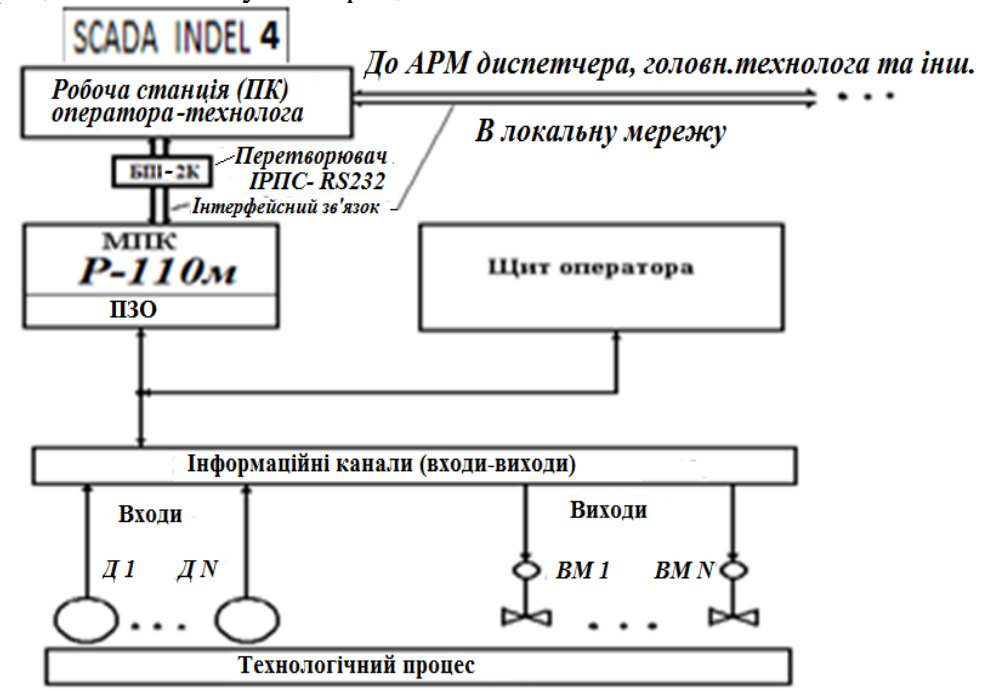

Рис. 1 - Структура АРМ оператора ВС до модернізації

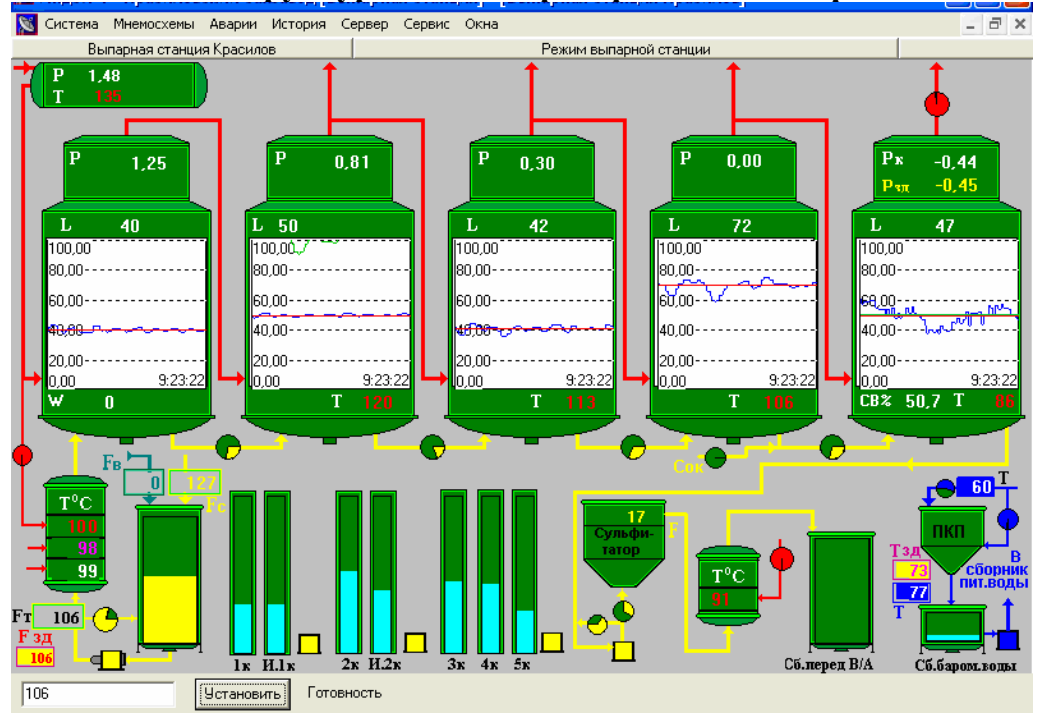

Рис. 2 - Основна екранна форма АРМ оператора ВС до модернізації 
Основна екранна форма АРМ оператора наведена на рис. 2. На формі відображені основні технологічні агрегати ВC, змінні процесу, що контролюються та регулюються, у тому числі у вигляді динамічних графіків деяких основних регульованих змінних.

На рис. 3 наведено зовнішній вигляд щитів оператора (основний та додатковий) до модернізації, на котрих розташовані прилади контролю та дистанційного керування, як електричні так i пневматичні, в тому числі перемикачі, задавачі та манометри, що показують тиск у лініях керування пневматичними виконавчими механізмами 3 регулюючими клапанами. На додатковому щиті встановлений мікропроцесорний контролер, що керуює.

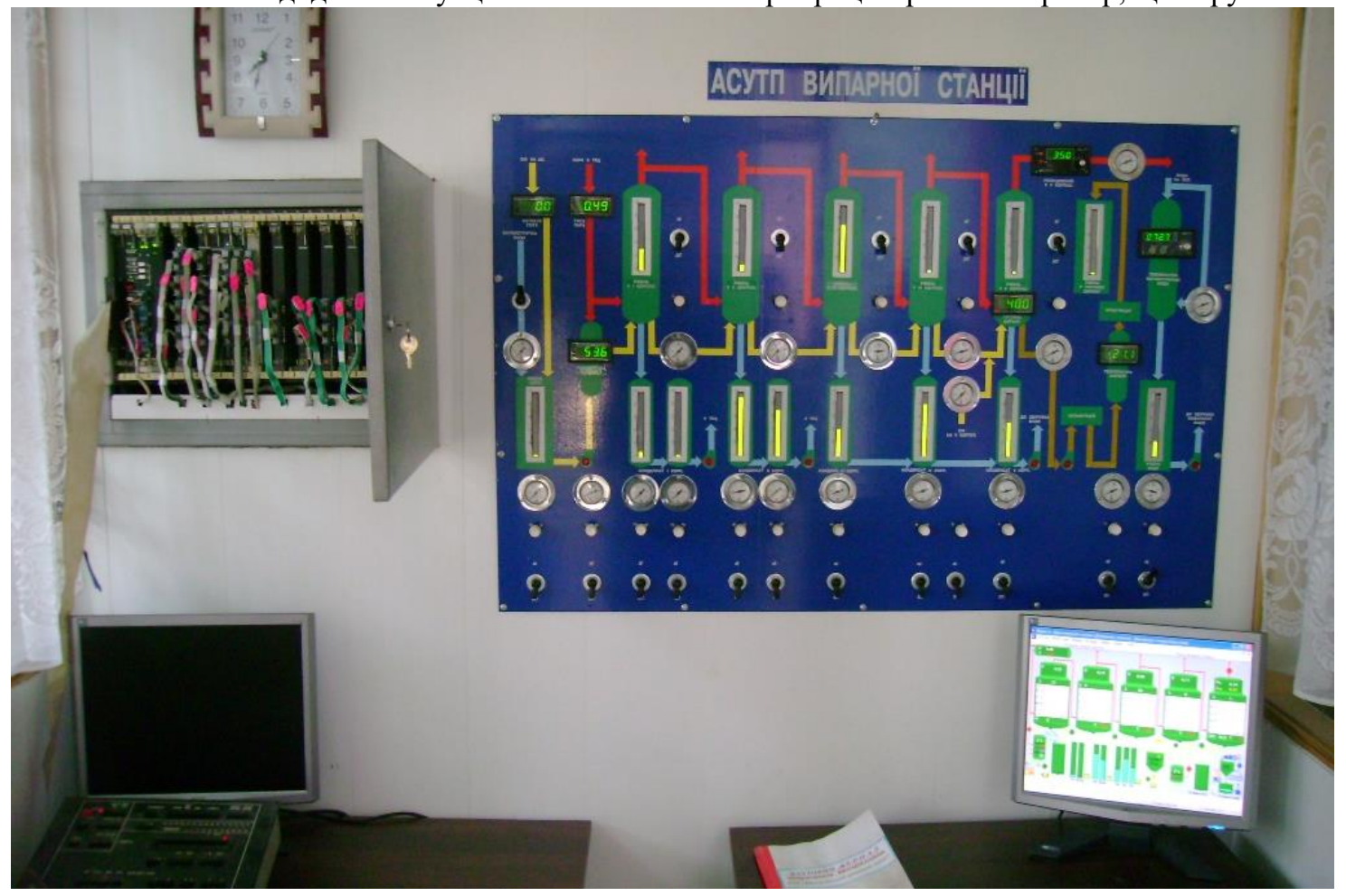

Рис. 3 - Щит оператора ВС до модернізації

Необхідність модернізації структури КТЗ АРМ ВС пов'язана із фізичним та моральним зношенням, як контролера (більш десяти років експлуатаціі), так і груп датчиків та виконавчих механізмів (більш тридцяти років).

Вибір лінії мікропроцесорних пристроїв провадився з урахуванням реальних можливостей персоналу служби головного метролога з освоєння й обслуговування подібної техніки. АСКТП на цьому підприємстві було реалізовано на базі програмованих мікропроцесорних контролерів вітчизняного виробництва й комп'ютерів, оснащених SCADAсистемою «ІНДЕЛ». Набір драйверів, що поставляються в комплекті 3 SCADA-системою, забезпечує обмін інформацією $з$ контролерами, як вітчизняного виробництва Реміконт (110, 130), МІК (підприємство «МІКРОЛ»), так і імпортного виробництва (Siemens, VIPA і ін.). Перевага була віддана програмованим контролерам МІК-52, мікропроцесорним регуляторам МІК-112, МТР-8, МІК-111н виходячи із критерію «вартість - якість», з урахуванням близькості програмного забезпечення для цього програмованого контролера (використовується редактор « $ф)$ до знайомого персоналу служби КВП і А редактору для мікропроцесорних контролерів (МПК), що функціонують на підприємстві. Крім того, проведені раніше роботи з модернізації АРМів котельного та дифузійного відділень [2, 3], 3 наступною експлуатацією цієї лінії контролерів та регуляторів показали їх надійність і зручність як для оперативного персоналу, так і для робітників служби головного метролога.

На ПК оператора установлена операційна система WINDOWS-XP, що забезпечує реалізацію всіх функцій SCADA-системи «ІНДЕЛ». Вибір останньої, замість запропонованої виробниками контролерів SCADA-системи «Visual Intellect», обумовлено насамперед простотою й зручністю роботи з налагодження драйвера MODBUS RTU, що включено у комплект поставки SCADA-Системи «ІНДЕЛ», що дозволяє забезпечити зв'язок з усіма контролерами фірми «МІКРОЛ», а також має досить розвинені функціональні можливості, добре знайомі як операторам, так i технічним керівникам підприємства, чиї робочі місця оснащені ПК.

Модернізація структури КТЗ системи керування супроводжувалась заміною застарілих датчиків та виконавчих механізмів. Відтак замість рівнемірів буйкового типу у всіх корпусах, збірниках конденсату та випарювачах встановлені ємносні рівнеміри, а в контурах керування рівнем замість пневматичних виконавчих механізмів із регулюючими клапанами - виконавчі механізми із поворотними заслінками (виробник - фipмa Camozzi). На рис. 4 
наведений новий збірник конденсату, оснащений системою керування рівня з використанням приладів, названих вище.

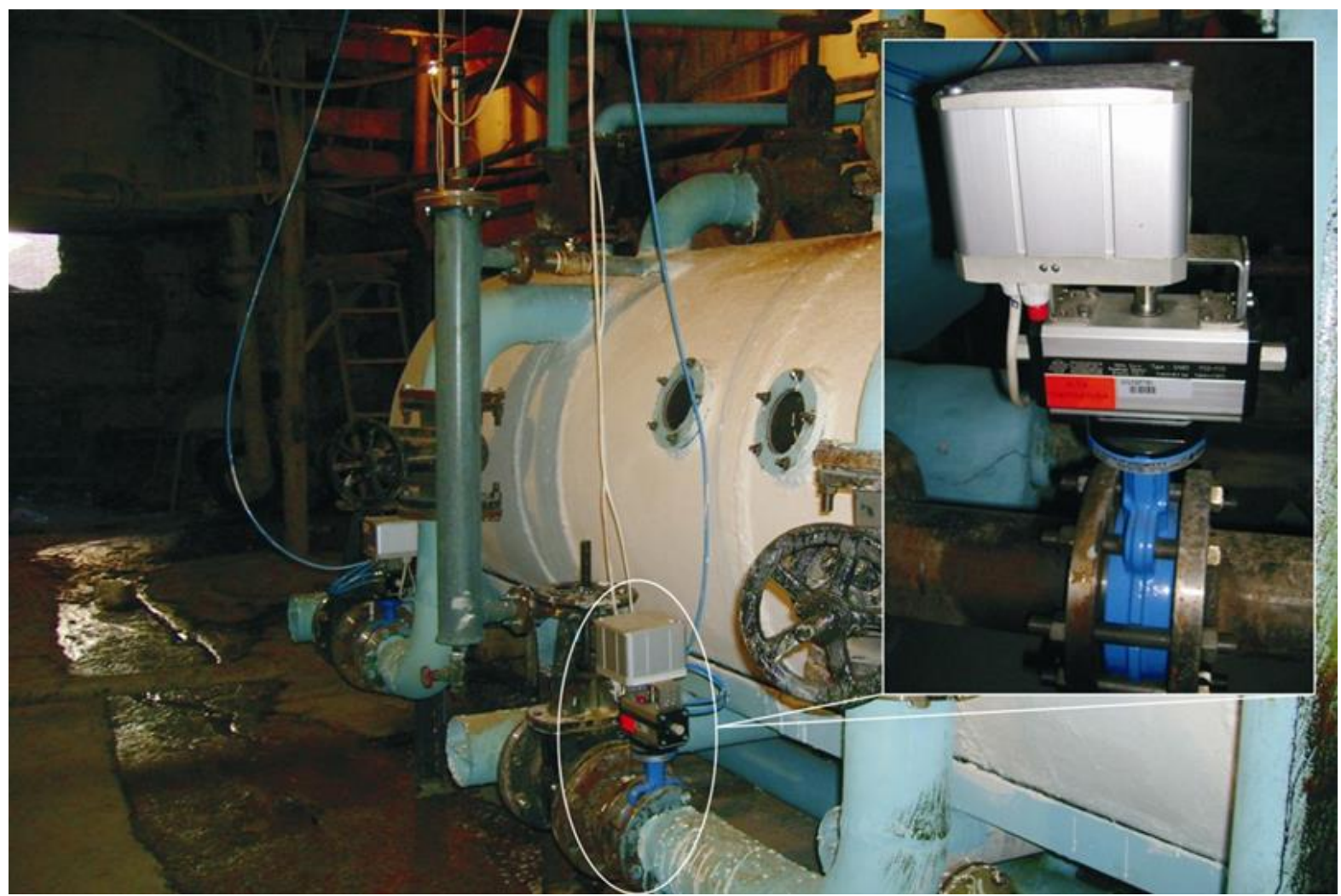

Рис. 4 - Реалізація контуру регулювання рівня в збірнику конденсату з використанням ємнісного рівнеміру та виконавчого механізму із поворотною заслінкою Camozzi

У складі АСКТП п’ятикорпусної випарної станції (ВС) крім традиційних задач контролю й регулювання регламентованих змінних, реалізована підсистема формування та подання даних для аналізу теплотехнічних показників роботи ВС, що забезпечує зручність аналізу роботи станції на різних рівнях керування (АРМах) для диспетчера (начальника зміни, теплотехніка), головного інженера, головного технолога, директора й т.п.

Випарна станція є основною ділянкою з точки зору формування теплових потоків цукрового заводу, тобто окрім основної функції - згущення дифузійного соку до стану сиропу (65\% сухих речовин), важливішою функцією є генерація вторинної пари, різних потенціалів, згідно до теплової схеми заводу. Тому, ритмічна робота ВС забезпечує подальшу ритмічність матеріальних (сиропних і теплових) потоків, особливо це важливо для продуктового відділення, куди з ВС поступають сироп, а також пара, що гріє.

Оновлення парку КТЗ та структури АРМ дозволяє забезпечити високу точність підтримки регламенту та розрахунку показників роботи ВС, що обумовлено кращими характеристиками нових технічних засобів.

Традиційні критерії керування заводом, прийняті у виробництві цукру, при їхній наочній інтерпретації можуть бути корисними не тільки при аналізі успішності функціонування підприємства за добу, декаду, місяць, але й при поточному аналізі внутрізмінної роботи. При необхідності, екранні форми, таблиці, графіки й т.П., можуть бути виведені на принтер і зведені в архіви паперових документів.

Дані, що представляються на АРМах, використовуються технічними керівниками заводу для оперативного контролю, аналізу й своєчасного прийняття рішень 3 керування технологічними процесами бурякоцукрового виробництва (коректування режимів, продуктивності й т.п.), оцінки роботи окремих змін і заводу в цілому.

Перелік завдань, реалізованих у складі АСКТП ВС, включає:

- $\quad$ контроль технологічних змінних процесу й стану встаткування (приводи насосів);

- регулювання:

- стабілізація:

- - рівнів: у корпусах ВС, збірниках конденсату та випарниках; у збірнику барометричної води;

- - витрати соку на ВC;

- - температур: соку та сиропу після підігрівачів; живильної води та гріючої пари з РОУ;

- $\quad$ - тиску гріючої пари на РОУ, розрідження у п’ятому корпусі ВС;

- $\quad$ - густини сиропу з ВС; 
- $\quad$ розрахунок:

• перепадів температур вторинних парів та їхніх тисків за корпусами ВС;

- показників роботи ВС.

Роботи з модернізації системи керування ВС виконувались у дві черги, згідно до фінансових можливостей підприємства. У першу чергу, модернізувалися системи регулювання нового «конденсатного господарства», а системи керування основних процесів ВС функціонували на централізованому контролері. На рис. 5 відображена структура контролерно-комп’ютерної мережі після виконання першої черги модернізації.

\section{В локальну}

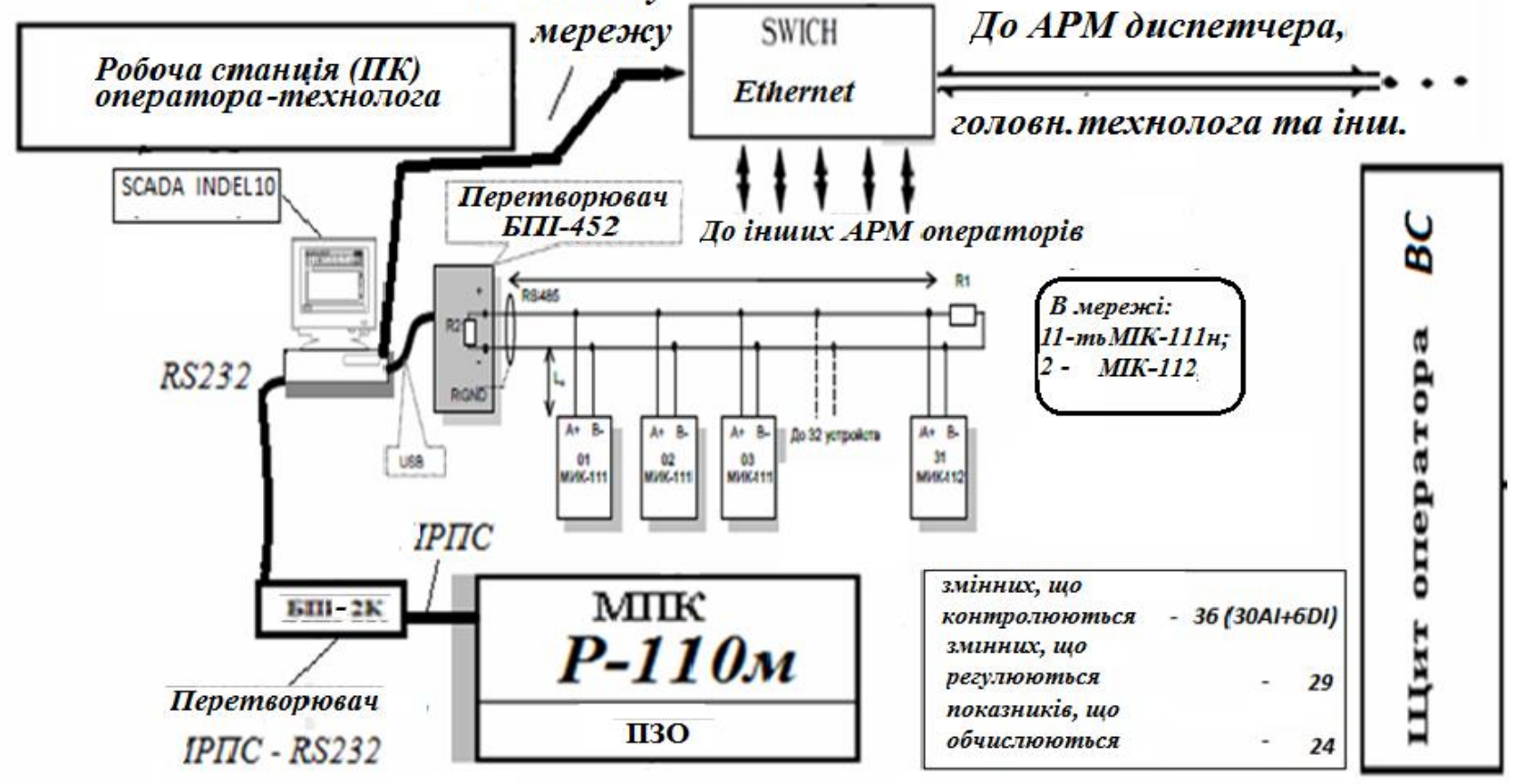

Рис. 5 - Структура КТЗ після виконання першої черги модернізації

У наведеній структурі в SCADA-системі «ІНДЕЛ», встановленій на ПК АРМ оператора, використовувались три типи драйверів для обміну (назви за документацією розробника): між ПК та централізованим МПК - драйвер Р110, між ПК та мережею регуляторів MIK - драйвер MODBUS, та драйвер «Вычислитель» для розрахунків, що виконуються на ПК.

Відповідно до модернізованої технологічної (теплотехнічної) схеми були розроблені скореговані екранні форми як основна, наведена на рис. 6 а, так і додаткова (рис. 6 б) з теплотехнічними показниками роботи ВС.

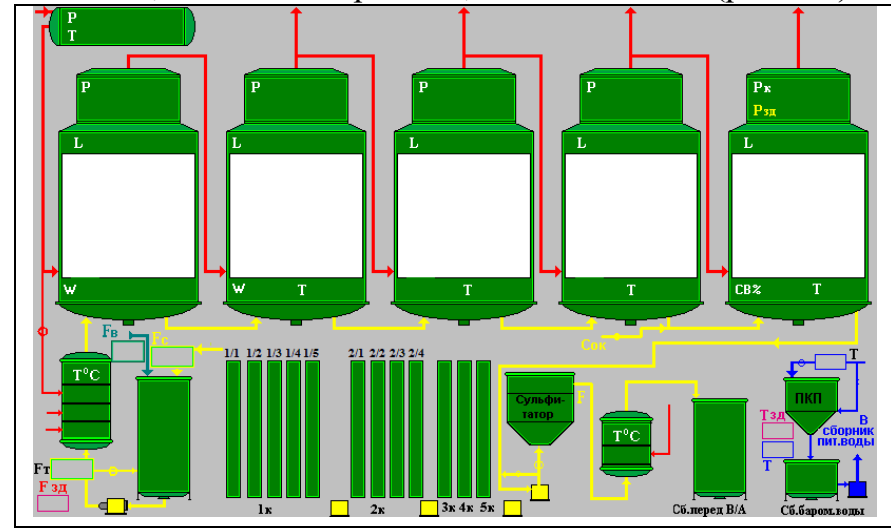

a)

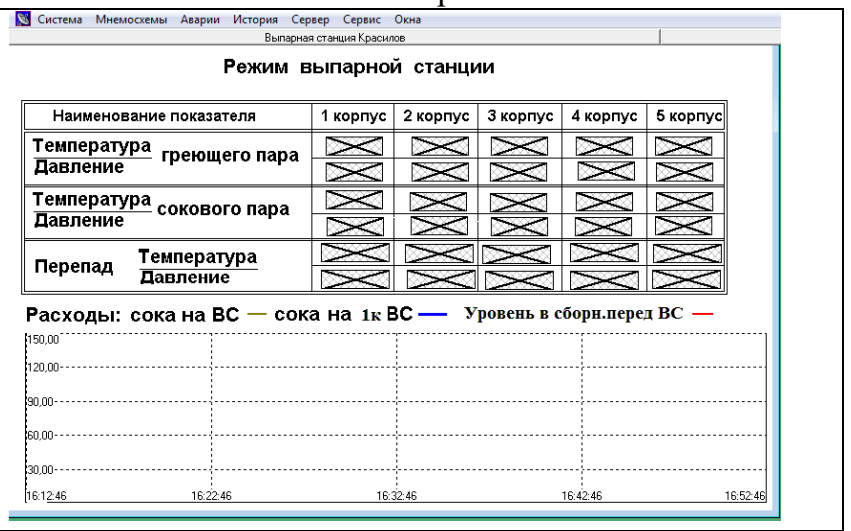

б)

Рис. 6 - Проекти екранних форм АРМ оператора ВС

На другому етапі модернізації централізований контролер був виключений зі структури КТЗ, а всі його функції, основні й додаткові, були реалізовані за допомогою мережі, що включає мікропроцесорний програмований контролер і мікропроцесорні регулятори. Підключення цієї мережі до ПК було виконано за допомогою того ж самого перетворювача інтерфейсів БПІ-452, котрий дозволяє підключати до чотирьох подібних мереж, для кожної 3 них 
програмним шляхом утворюється окремий віртуальний СОМ-порт, що дозволяє поєднати кожну мережу через відповідний порт з SCADA-системою «ІНДЕЛ».

На рис. 7 наведено остаточну структуру КТЗ, що була реалізована після виконання другої черги модернізації АРМ оператора ВC.

Передпроектні дослідження проводились на спеціалізованому лабораторному стенді. Цей імітаційний стенд містив: МПК: МІК-52, МТР-8, МІК-111н, МІК-112; аналогові задавачі РЗД-22 (зі струмовим виходом 4,...,20 мА), блок перетворення інтерфейсів БПІ-52, комп'ютер із установленим програмним забезпеченням: драйвер для БПІ-52 , редактор «а», SCADA-система «IНДЕЛ» із драйвером MODBUS RTU, що забезпечує обмін даними із контролером та регуляторами за двохдротяним інтерфейсом RS-485.

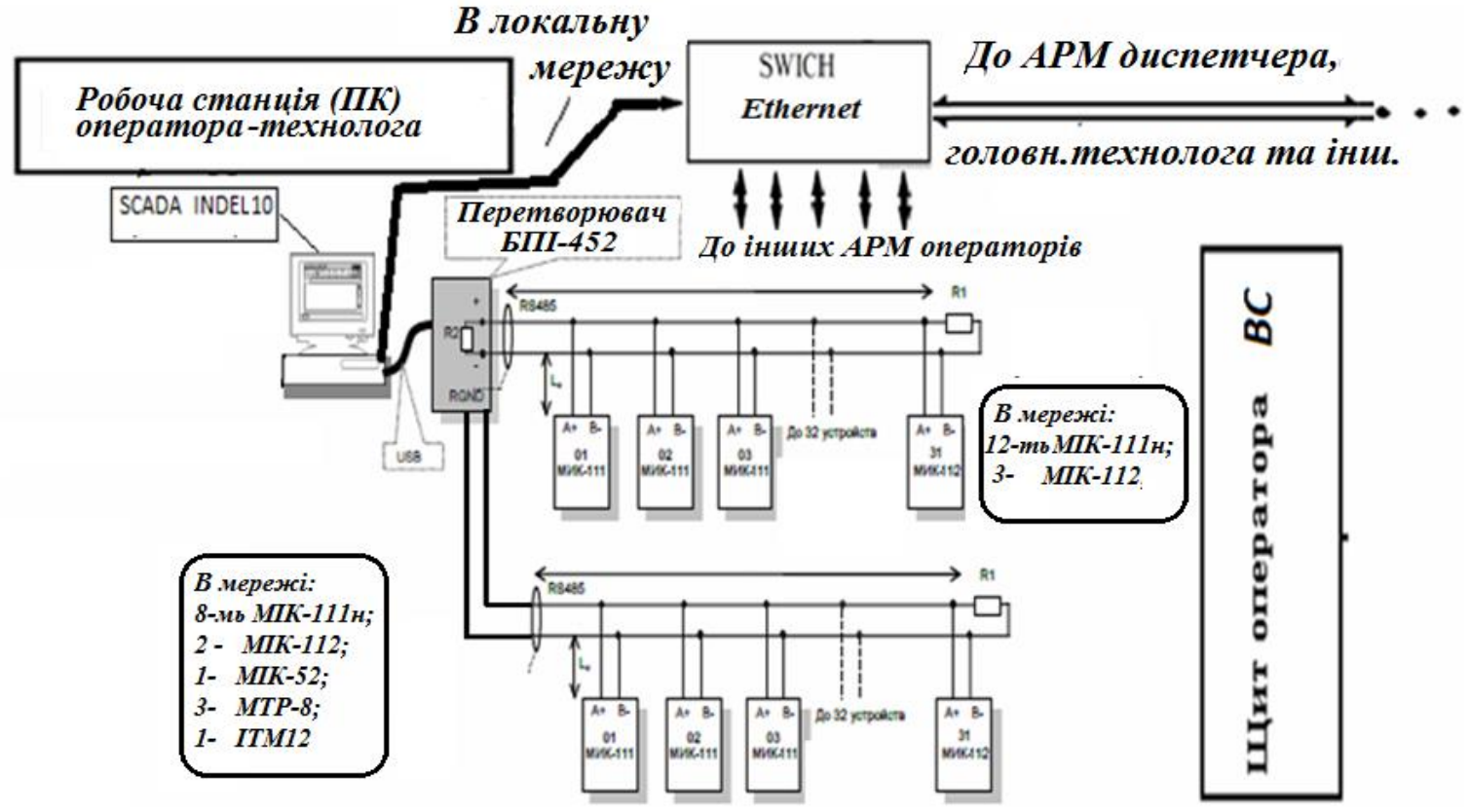

Рис. 7 - Структура КТЗ після виконання другої черги модернізації

Програмну реалізацію деяких алгоритмів регулювання та програмно-логічного керування виконано на програмованому контролері МІК-52 у редакторі « $2 »$. Фрагмент програми, що реалізує контроль змінних, регулювання витрати соку на перший корпус, аварійну подачу сульфітованої води та управління подачею повітря у відбірний пристрій датчика густини сиропу, наведений на рис. 8.

Регулювання витрати соку на перший корпус ВС здійснюється за допомогою частотного перетворювача, завдання якому в дистанційному режимі оператор може вводити з екранної форми.

Аварійна подача аміачної (сульфітованої) води в перший корпус здійснюється для захисту поверхні нагріву апарату у випадку зниження рівня в ньому нижче граничного.

Генератор імпульсів подачі повітря у відбірний пристрій датчика густини сиропу буйкового типу забезпечує налагоджувану періодичну короткострокову подачу бульбашок повітря для запобігання застою та кристалізації сиропу у відбірному пристрої.

Щит оператора ВС також був модернізований із заміною як основної так і додаткової панелей (рис. 9 а, б). На основній панелі розташовані вбудовані в мнемосхему ВС цифрові прилади, що показують, вузли дистанційного керування для контурів стабілізації рівнів продуктів у корпусах та конденсату в збірниках та випарювачах. Останні складаються із електричних перемикачів (кнопкового типу із підсвітлюванням стану контуру) та задавачів типу БРУ 1. На додатковій панелі розташований мікропроцесорний програмований контролер МІК-52 та група мікропроцесорних регуляторів МТР-8, МІК-112.

Особливістю виконання щита оператора $€$ відмова від використання клемних з'єднань між внутрішніми та зовнішніми проводками, тому що цей щит панельного типу монтувався безпосередньо на місці його наступної експлуатації.

Усі блоки живлення 220/24 В, що обрані в проекті, мають функцію стабілізації вихідної напруги, а ПК АРМ оператора живиться за допомогою джерела безперебійного живлення.

Відповідно до змін інформаційної підсистеми АРМ оператора ВС, внесені зміни в програмне забезпечення, для їхнього відображення, у АРМах технічних керівників заводу, що отримують усю потокову інформацію з локальної комп'ютерної мережі.

Модернізована система керування ВС здана в промислову експлуатацію й функціонує два сезони (2016/2017 р. перша черга модернізації, 2017/2018 р. - друга черга). Досвід іiї експлуатації підтвердив раціональність прийнятих за 
результатами проведених передпроектних досліджень технічних рішень, які забезпечили досягнення поставлених цілей, зокрема, підвищення точності підтримання регламентів ведення процесу, зручності використання оперативним персоналом, та дозволив адаптувати дану систему в структуру багаторівневої АСКТП заводу.

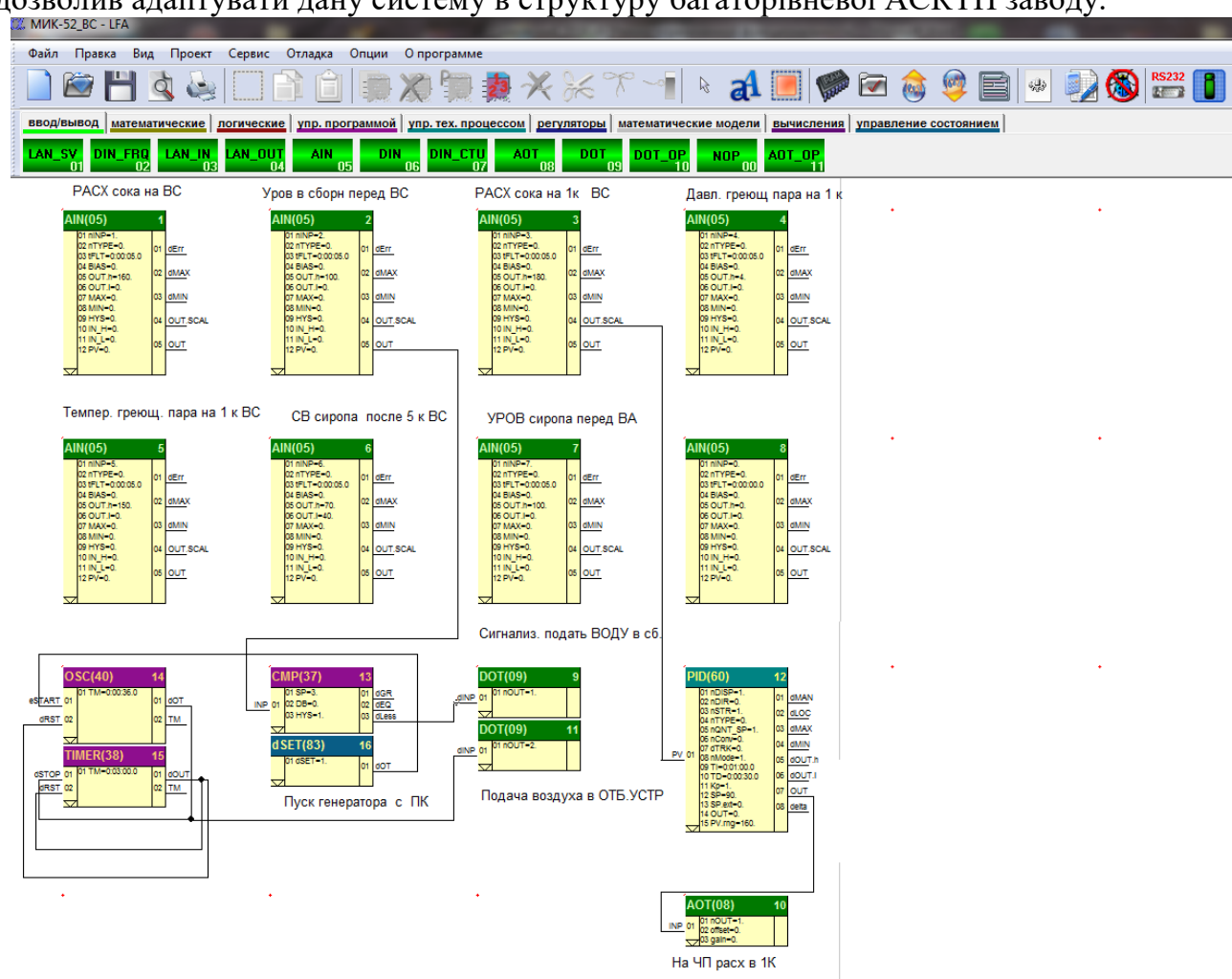

Рис. 8 - Фрагмент програми на мові «а» для контролера МІК-52

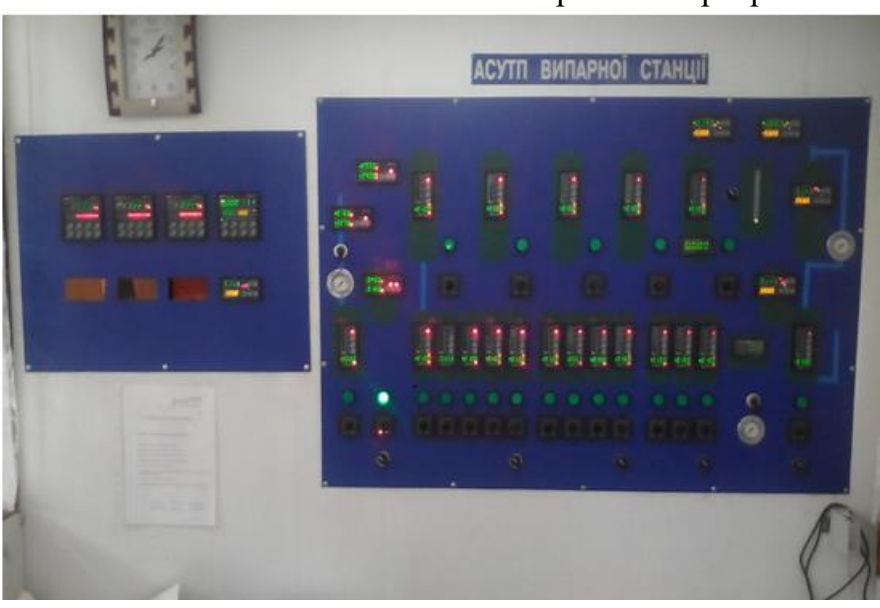

a)

Рис. 9 - Модернізований щит оператора ВС:

а) - вид на фронтальну площину щита;

б) - вид на задню стінку щита, де змонтована мережа мікропроцесорних регуляторів МІК-111н
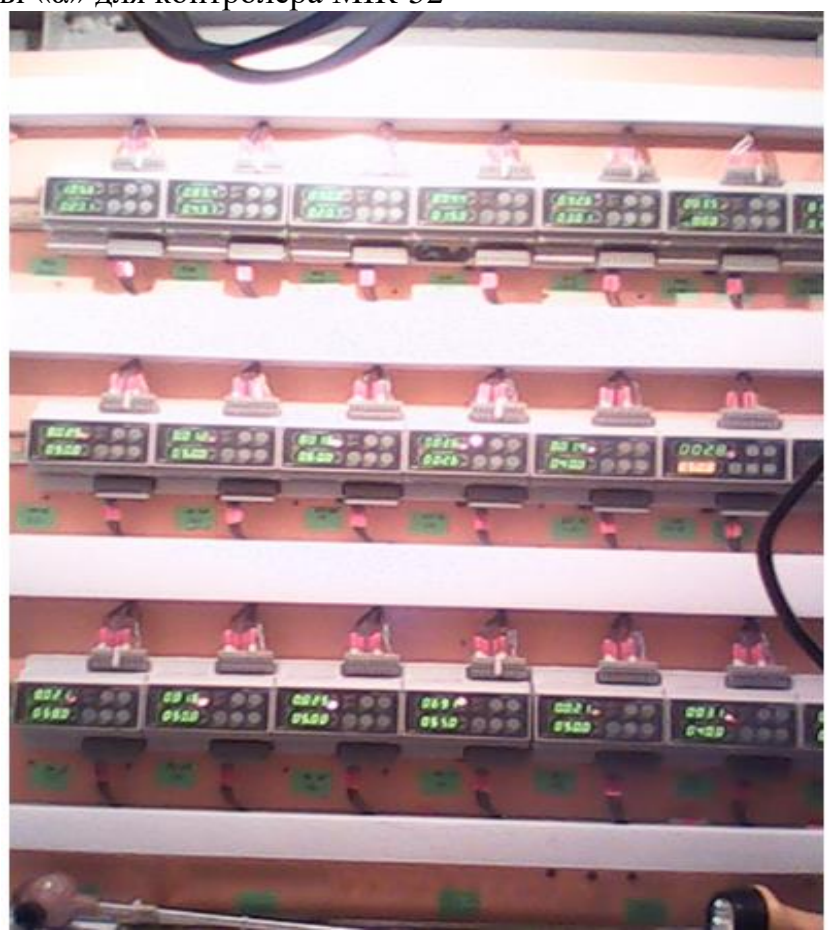

б)

\section{Висновки.}

Проведені передпроектні дослідження з використанням методів імітаційного моделювання на спеціалізованому стенді, котрий було обладнано промисловими контролерами та регуляторами, дозволили розробити комплекс технічних рішень, що забезпечує успішну експлуатацію модернізованої системи керування ВС. 
Технічні й програмні засоби Українського виробництва забезпечують точність підтримання регламентів ведення процесу, досить комфортні умови, як розробникам систем керування, так і оперативному персоналу підприємства.

Виконаний комплекс робіт дозволяє зробити висновок про доцільність продовження робіт із модернізації систем керування підприємства, використовуючи подібні методи й підходи до прийняття основних технічних рішень.

\title{
Література
}

[1] Жуковский Э.И. Реализация задачи оценивания показателей работы завода в АСУТП сахарного производства/ Э.И. Жуковский, Ю.М. Скаковский, В.Д. Витвицкий, А.В. Бабков // Автоматизация технологических и бизнеспроцессов. - Одесса: 2010 - №3.- С.16-26.

[2] Skakovsky Y. M. Increasing of precise estimation of optimal criteria boiler functioning/ Y. M. Skakovsky, A. V. Babkov, E. Y. Mandro //Automation of technological and business-processes. - Odessa:Volume 8, Issue 2/2016/ pp. 58-65.

[3] Скаковський Ю. М. Использование микропроцессорных контроллеров и программ украинского производства для модернизации системы управления диффузионного отделения сахарного завода/ Ю. М. Скаковский, А. В. Бабков // Автоматизация технологических и бизнес-процессов. - Одесса: 2015 - №7(3), С. 46-51.

\section{Referens}

[1] E.Y. Gukovskiy, Y.M. Skakovskiy, V.D. Vitvitskiy, A.V. Babkov. Realizacia zadachi ocenivania pokazateley raboti zavoda v ASUTP saharnogo proizvodstva. Odessa: Avtomatizacia tehnologicheskih i biznes-procesov. 2010 - №3.pp.16-26.

[2] Y. M. Skakovsky, A. V. Babkov, E. Y. Mandro. Increasing of precise estimation of optimal criteria boiler functioning. Odessa: Automation of technological and business-processes. Vol.8, Issue 2/2016/ pp. 58-65.

[3] Y. M. Skakovsky, A. V. Babkov. Ispolzovanie microprocessornikh kontrollerov i program ukrainskogo proizvodstva dlya modernizacii sistemupravleniya diffuzionnogo otdeleniya sakharnogo zavoda. technological and business-processes. 2015 - №7(3), pp. 46-51.

\section{КЛАСИФІКАЦІЯ ЗАВДАНЬ І ПРИНЦИПІВ УПРАВЛІННЯ МЕХАНІЗМОМ ПАРАЛЕЛЬНОЇ КІНЕМАТИЧНОЇ СТРУКТУРИ ДЛЯ ВИРІШЕННЯ РІЗНИХ ЗАВДАНЬ}

\author{
Зозуля В.Аํ. Осадчий С.І. ${ }^{2}$, Бєлясв Ю. Б. ${ }^{3}$, Paweł Pawłowski ${ }^{4}$ \\ ORCID: ${ }^{1}$ 0000-0003-3793-4686, ${ }^{2} 0000-0002-1811-3594,{ }^{3} 0000-0002-1811-3594$ \\ ${ }_{1,2}$ Центральноукраїнський національний технічний університет, Кропівницький \\ ${ }^{3}$ Національний університет харчових технологій, м. Київ \\ ${ }^{4}$ Познанський технологічний університет, м. Познань, Польща \\ E-mail: irish38@ukr.net,srg2005@ukr.net, belyaevyb@ukr.net,pawel.pawlowski@put.poznan.pl
}

Copyright (C) 2018 by author and the journal "Automation technologies and business - processes. This work is licensed under the Creative Commons Attribution International License (CC BY). http://creativecommons.org/licanses/by/4.0

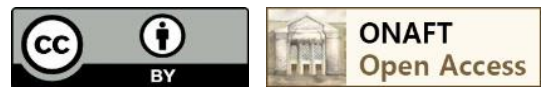

\section{DOI: $10.15673 /$ atbp.v10i1.874}

Наведено класифікацію механізмів паралельної кінематичної структури на основі платформи Стюарта (гексапод) за видами робіт, щзо виконуються. Це оброблювальні цеентри (верстати), координаційно-вимірювальні центри, вібрачійні платформи (стенди для випробувань), симулятори (руху), стабілізаційна платформа. Показано, щзо існують технологічні завдання при яких механізм паралельної кінематичної структури на основі платформи Стюарта (гексапод) здійснює рух, точно слідуючи бажаної траєкторії і положенню орієнтачї в певному часовому 